\title{
Author Correction: Liquid versus tissue biopsy for detecting acquired resistance and tumor heterogeneity in gastrointestinal cancers
}

Aparna R. Parikh, Ignaty Leshchiner (D), Liudmila Elagina, Lipika Goyal, Chaya Levovitz, Giulia Siravegna, Dimitri Livitz $(\mathbb{D}$, Kahn Rhrissorrakrai, Elizabeth E. Martin, Emily E. Van Seventer, Megan Hanna, Kara Slowik, Filippo Utro (i),

Christopher J. Pinto, Alicia Wong, Brian P. Danysh, Ferran Fece de la Cruz (D), Isobel J. Fetter, Brandon Nadres (1), Heather A. Shahzade, Jill N. Allen, Lawrence S. Blaszkowsky, Jeffrey W. Clark, Bruce Giantonio, Janet E. Murphy, Ryan D. Nipp, Eric Roeland, David P. Ryan, Colin D. Weekes, Eunice L. Kwak, Jason E. Faris, Jennifer Y. Wo,

François Aguet (D, Ipsita Dey-Guha, Mehlika Hazar-Rethinam, Dora Dias-Santagata, David T. Ting (D), Andrew X. Zhu, Theodore S. Hong, Todd R. Golub (1), A. John lafrate, Viktor A. Adalsteinsson, Alberto Bardelli, Laxmi Parida (1),

Dejan Juric (D), Gad Getz $\mathbb{D}$ and Ryan B. Corcoran (1D)

Correction to: Nature Medicine https://doi.org/10.1038/s41591-019-0561-9, published online 9 September 2019.

In the version of this article initially published, 'FPO-IRCCS' was omitted in affiliation 5; the correct affiliation is Candiolo Cancer Institute, FPO-IRCCS, Candiolo, Italy. The error has been corrected in the HTML and PDF versions of the article.

Published online: 19 November 2019

https://doi.org/10.1038/s41591-019-0698-6

() The Author(s), under exclusive licence to Springer Nature America, Inc. 2019

\section{Publisher Correction: Artificial intelligence aims to improve cancer screenings in Kenya}

Nicole Wetsman

Correction to: Nature Medicine https://doi.org/10.1038/s41591-019-0629-6, published online 16 October 2019.

This article originally did not mention the funding support from the Karolinska Institute. It has been amended to reflect this aspect of the project. The error has been corrected in the HTML and PDF versions of the article.

Published online: 19 November 2019

https://doi.org/10.1038/s41591-019-0699-5

๑) Springer Nature America, Inc. 2019 